\title{
Endocrinopathies in survivors of childhood neoplasia
}

\author{
Nicole Barnes ${ }^{1}$ and Wassim Chemaitilly ${ }^{1,2}$ * \\ 1 Division of Pediatric Endocrinology, Department of Pediatric Medicine, St. Jude Children's Research Hospital, Memphis, TN, USA \\ ${ }^{2}$ Epidemiology and Cancer Control, St. Jude Children's Research Hospital, Memphis, TN, USA
}

\section{Edited by:}

Selma Feldman Witchel, University of Pittsburgh, USA

\section{Reviewed by:}

Alan David Rogol, University of

Virginia, USA

Eli Hershkovitz, Soroka Medical

University Center, Israel

Laurie E. Cohen, Boston Children's

Hospital, USA

\section{*Correspondence}

Wassim Chemaitilly, Division of Pediatric Endocrinology, St. Jude

Children's Research Hospital, 262

Danny Thomas Place, Mail Stop 737,

Memphis, TN 38105, USA

e-mail: wassim.chemaitilly@

stjude.org
Advancements in cancer treatments have increased the number of survivors of childhood cancers. Endocrinopathies are common complications following cancer therapy and may occur decades later. The objective of the current review is to address the main endocrine abnormalities detected in childhood cancer survivors including disorders of the hypothalamic-pituitary axis, thyroid, puberty, gonads, bone, body composition, and glucose metabolism.

Keywords: endocrinology, growth, puberty, gonads, childhood cancer survivors, thyroid disorders

\section{INTRODUCTION}

Approximately 1 in 285 children will be diagnosed with cancer before the age 20 years, and 1 in 530 young adults between the ages of 20 and 39 years is a childhood cancer survivor (CCS) (1). Endocrine complications are among the most common sequelae observed in CCS, and they frequently occur as cancer therapyrelated late - effects appearing years, even decades, after the exposure to chemotherapy and/or radiotherapy. The prevalence of an endocrine disorder in 1423 at risk adult CCS was reported to be $62 \%$ (95\% CI 59.5-64.6) (2). The 60-year cumulative risk of having an endocrinopathy in an individual diagnosed with cancer between the ages of 5 and 9 years was $43 \%$ in a large cohort of Northern European CCS (3). The occurrence of endocrine disorders documented in an Italian Transition Unit for adult CCS was 48.46 and $62.78 \%$ in females and males, respectively (Figure 1) (4). Treatment exposures placing individuals at risk of endocrinopathies have traditionally included alkylating agent based chemotherapy and radiotherapy. More recently, selective mitogen-activated kinase inhibitors and immune system modulators have been shown to also be associated with endocrine dysfunction. The long-term consequences of the use of these novel therapies, some of which are prescribed in maintenance regimens, remain to be fully elucidated (5-7). Healthcare providers should be equipped to diagnose and manage acute and longterm endocrine complications that may arise in maturing CCS. This review will address the risk of endocrine disorders associated with the treatment of pediatric cancer and brain tumors. The data summarized in this review are based on a systematic search of the medical literature using MEDLINE/Pubmed (from 1970 to May 2014) using keywords relevant to this topic. Additional searches were conducted within the reference lists of relevant articles.

\section{DISORDERS OF THE HYPOTHALAMUS AND PITUITARY}

Tumor development and/or surgical resections close to the hypothalamus and/or pituitary may induce direct anatomical damage to these structures and result in multiple hypothalamic/pituitary dysfunctions (Table 1). Disorders of the hypothalamus/pituitary are also common following their exposure to direct or scatter radiotherapy. More recently, Ipilimumab, an immune system modulator, was shown to potentially cause auto-immune hypophysitis with ensuing anterior panhypopituitarism (7). Pituitary dysfunction was the most frequent endocrine complication in a Northern European cohort comparing 31,723 CCS and 211,261 controls. In this study, the standard hospitalization rate ratio of hypopituitarism was 88.0 (95\% CI 72.1-107.5) in CCS when compared to matched controls from the local general population (3).

\section{GROWTH HORMONE DEFICIENCY AND POOR LINEAR GROWTH}

Growth failure and short stature are among the most common sequelae of childhood cancer therapy (8). Several etiologies may contribute to growth failure in CCS including growth hormone deficiency (GHD), exposures to spinal and total-body irradiation (TBI), pubertal disorders, chemotherapy treatments including glucocorticoids, hypothyroidism, suboptimal nutrition, and renal disease (9-12).

In CCS, GHD is frequently attributed to cranial radiotherapy doses of 12-64 Gy to the hypothalamus/pituitary (4). Radiation has a dose and time dependent effect on GH secretion. Merchant et al. demonstrated that GHD was likely to develop within 36 months of exposure to hypothalamic/pituitary radiotherapy in individuals receiving doses $\geq 20 \mathrm{~Gy}$ (13) (Figure 2). In comparison to radiotherapy, the impact of chemotherapy alone on GHD secretion is more controversial and less common (14-17). Imatinib, a tyrosine kinase inhibitor (TKI), has been associated with 


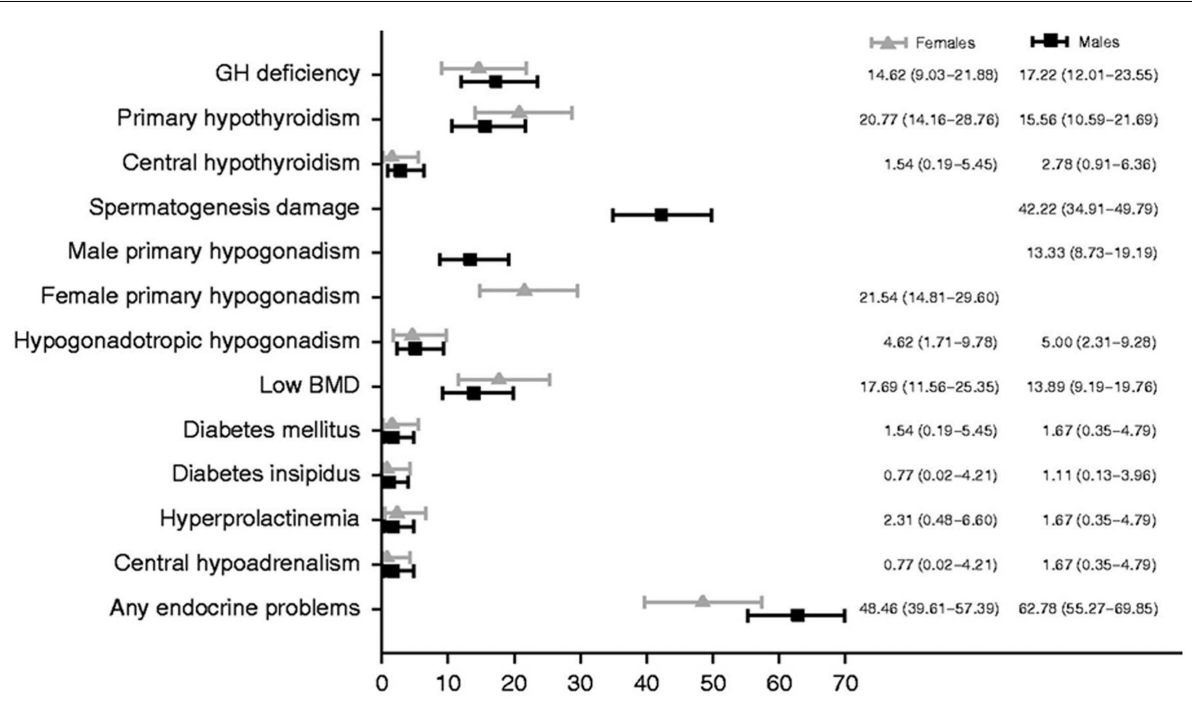

FIGURE 1 | Prevalence of endocrine disorders at the last follow-up visit by gender. Reproduced with permission from Ref. (4) @2013 European Society of Endocrinology.

growth deceleration and with failure of provocative GH stimulation testing $(18,19)$. Imatinib is presumed to inhibit bone growth by impeding the kinase mediated release of GH (5).

Growth hormone deficiency should be investigated in skeletally immature CCS when linear growth velocity decelerates over a 6-month period. The effect of GHD on growth may be masked by precocious puberty and by hyperinsulinemia in the context of rapid weight gain ("growth without growth hormone") with seemingly normal linear growth driven by sex steroids and insulin respectively in affected individuals $(20,21)$. CCS exposed to spinal radiotherapy are at risk of having skeletal disproportions; this should ideally be investigated by measuring the sitting height (12). Biochemical evaluation for GHD requires dynamic testing, which despite limitations related to poor reproducibility in the general population, remains acceptable for the assessment of GH secretion in CCS (22). In the general population, the diagnosis of GHD typically requires failing dynamic tests using two different secretagogues; however, in CCS exposed to cranial radiotherapy and individuals with a history of a brain tumor close to the hypothalamus/pituitary, failing one test was considered sufficient in the consensus guidelines published by the Growth Hormone Research Society (23). Secretagogues used in dynamic testing include insulin, arginine, levodopa, clonidine, and glucagon. GH releasing hormone (GHRH) should not be used for the assessment of GH secretion in this population given the primarily hypothalamic location of radiation-induced damage (24). Plasma levels of IGF-1 and IGFBP3, although commonly practiced, are not reliable screening tools in CCS exposed to cranial radiotherapy and are associated with high rates of false-negatives (25).

Treatment with recombinant $\mathrm{GH}(\mathrm{rGH})$ replacement therapy is typically not initiated until 12 months after successfully completing cancer or brain tumor treatments. The mitogenic potential of GH stimulating tumor growth is a safety concern in CCS (26). Studies suggest that rGH in patients with brain tumors are not associated with primary disease recurrence (27-29). However, there may be an increase in the development of second neoplasm in CCS treated with GH $(30,31)$. Ergun-Longmire et al. reported a relative risk of 2.15 ( $95 \% \mathrm{CI}, 1.3-3.5 ; p<0.002)$ of developing a second neoplasm in CCS treated with rGH when compared to controls and the most commonly identified neoplasms were meningiomas (30). Nevertheless, using the same multi-center cohort of CCS and reporting specifically on the risk of subsequent central nervous system neoplasms after a longer period of follow-up, Patterson et al. recently reported an adjusted rate ratio of meningioma and gliomas in GH treated survivors of CNS tumors when compared to CNS tumor survivors who were not treated with $\mathrm{GH}$ of 1.0 (95\% CI $0.6-1.8, p=0.94)$, thus indicating negligible differences between the two groups in regards to this particular risk (32).

The benefits of rGH extend beyond linear growth and are highlighted in adult GHD studies. Some of the advantages include improvements in bone mineral density (BMD), cardiovascular function, reduction in metabolic syndrome, and sustained improvements in quality of life (33). The benefits and risk of rGH have to be carefully weighed in children and adult survivors. Ongoing studies are needed to investigate and characterize the risk of developing second neoplasms as well as the proposed advancements in the physiological and psycho-social well-being of rGH in CCS.

\section{DISORDERS OF LUTEINIZING HORMONE AND FOLLICLE-STIMULATING HORMONE Central precocious puberty}

Central precocious puberty (CPP) is defined by the early activation of the hypothalamic-pituitary-gonadal axis leading to the onset of puberty prior to the ages of 8 and 9-years in girls and boys, respectively $(34,35)$. The consequences of CPP include the premature closure of growth plates resulting in decreased adult height prospects. Precocious puberty, especially menarche, can generate 
Table 1 | Central endocrinopathies

\begin{tabular}{|c|c|c|c|c|c|}
\hline Function & Complication & Therapy-related risks & $\begin{array}{l}\text { Relationship to time, dose to gland, } \\
\text { or organ when applicable }\end{array}$ & Evaluation/labs & Intervention \\
\hline \multirow[t]{2}{*}{$\begin{array}{l}\text { Linear } \\
\text { growth }\end{array}$} & \multirow[t]{2}{*}{ GH deficiency } & Surgery & $\begin{array}{l}\text { Damage to the pituitary by tumor } \\
\text { expansion and/or surgery }\end{array}$ & $\begin{array}{l}\text { Bone age } \\
\text { IGF1, IGF-BP3 }\end{array}$ & $\mathrm{GH}$ replacement \\
\hline & & $\begin{array}{l}\text { Radiotherapy to } \\
\text { hypothalamus/pituitary }\end{array}$ & Doses $\geq 18$ Gy (highest risk $\geq 30$ Gy) & GH stimulation test & \\
\hline & $\begin{array}{l}\mathrm{LH} / \mathrm{FSH} \\
\text { deficiency }^{\mathrm{a}}\end{array}$ & $\begin{array}{l}\text { Surgery } \\
\text { Radiotherapy to } \\
\text { hypothalamus/pituitary }\end{array}$ & $\begin{array}{l}\text { Damage to the pituitary by tumor } \\
\text { expansion or growth } \\
\text { Doses } \geq 30 \mathrm{~Gy} \\
\text { Partial deficit } \geq 20 \mathrm{~Gy}\end{array}$ & $\begin{array}{l}\text { Bone age } \\
\text { Baseline AM LH, FSH, estradiol } \\
\text { (girls), or testosterone (boys) }\end{array}$ & $\begin{array}{l}\text { Induction of } \\
\text { puberty/sex } \\
\text { hormone } \\
\text { replacement therapy }\end{array}$ \\
\hline & & $\begin{array}{l}\text { Irradiation to } \\
\text { hypothalamus or pituitary }\end{array}$ & Doses $\geq 30 \mathrm{~Gy}$ & $\begin{array}{l}\text { Low dose ACTH stimulation } \\
\text { test if AM cortisol is abnormal }\end{array}$ & \\
\hline & & Systemic glucocorticoids & $\begin{array}{l}\text { Deficiency depends on the doses used } \\
\text { and duration of exposure }\end{array}$ & & \\
\hline & \multirow[t]{2}{*}{$\begin{array}{l}\text { TSH } \\
\text { deficiency }^{a}\end{array}$} & Surgery & $\begin{array}{l}\text { Damage to the pituitary by tumor } \\
\text { expansion and/or surgery }\end{array}$ & Free T4 & Levothyroxine \\
\hline & & $\begin{array}{l}\text { Radiotherapy to } \\
\text { hypothalamus/pituitary }\end{array}$ & Doses $\geq 30 \mathrm{~Gy}$ & & \\
\hline & $\begin{array}{l}\text { Central } \\
\text { diabetes } \\
\text { insipidus }\end{array}$ & Surgery & $\begin{array}{l}\text { Damage to the pituitary by tumor } \\
\text { expansion and/or surgery }\end{array}$ & $\begin{array}{l}\text { Plasma electrolytes, serum, } \\
\text { and urinary osmolalities. Water } \\
\text { deprivation test in equivocal } \\
\text { situations }\end{array}$ & $\begin{array}{l}\text { Desmopressin } \\
\text { Fluid management }\end{array}$ \\
\hline
\end{tabular}

GH, growth hormone; IGF-1, insulin-like growth factor-1; IGF-BP3, insulin-like growth factor binding protein 3; GnRH, gonadotropin releasing hormone; ACTH, corticotropin; TSH, thyroid stimulating hormone; AM, morning sample; LH, luteinizing hormone; FSH, follicle-stimulating hormone.

${ }^{a}$ Also described in the context of ipilimumab-induced anterior hypophysitis.

significant psycho-social adjustment challenges in young children, particularly in those with special needs. While radiotherapy to the hypothalamus/pituitary is the main risk factor associated with CPP in CCS; pubertal development can also be triggered prematurely by tumors located near the hypothalamus or optic pathways independently from radiation exposure. Additional risk factors include hydrocephalus, female sex, exposure to radiotherapy before the age of 5 years, and increased BMI $(36,37)$.

The mean linear velocity in children with $\mathrm{CPP}$ can be 8 $10 \mathrm{~cm} /$ year ( +2 to $+4 \mathrm{SDS}$ for chronological age) at diagnosis (38); however, in CCS the linear growth velocity may be normal or poor secondary to concurrent GHD or spinal damage from radiotherapy (39). Clinicians should not rely on the measurement of testicular volume for the diagnosis of puberty in males exposed to gonadotoxic chemotherapy regimens (as those with alkylating agents) and/or testicular irradiation. In these individuals, treatment-related germ cell injury can impair testicular growth without necessarily affecting their ability to produce testosterone and this can be particularly misleading in the context of CPP. Clinicians should be aware of these caveats and have a low threshold to initiate laboratory testing if there is suspicion of early pubertal growth based on other clinical markers such as penile enlargement, scrotal skin thinning, or pubarche.

Biochemical evidence of CPP includes pubertal basal levels of luteinizing hormone (LH) and sex steroids (estradiol or testosterone). Random basal values may be inconclusive secondary to the pulsatile nature of gonadotropins and stimulated values may be necessary to establish the diagnosis. GnRH agonists are used in stimulation testing and a pubertal $\mathrm{LH}$ value and a $\mathrm{LH}$ to follicle-stimulating hormone (FSH) ratio $>1$ is consistent with CPP $(34,40)$. Radiographic evaluation encompasses an assessment of a child's skeletal maturation $(41,40)$. In females a pelvic ultrasound demonstrating pubertal sized uterus and ovaries may also be helpful in confirming the diagnosis (42).

Treatment with a GnRH agonist suppresses the secretion of gonadotropins and may be useful in improving final height 


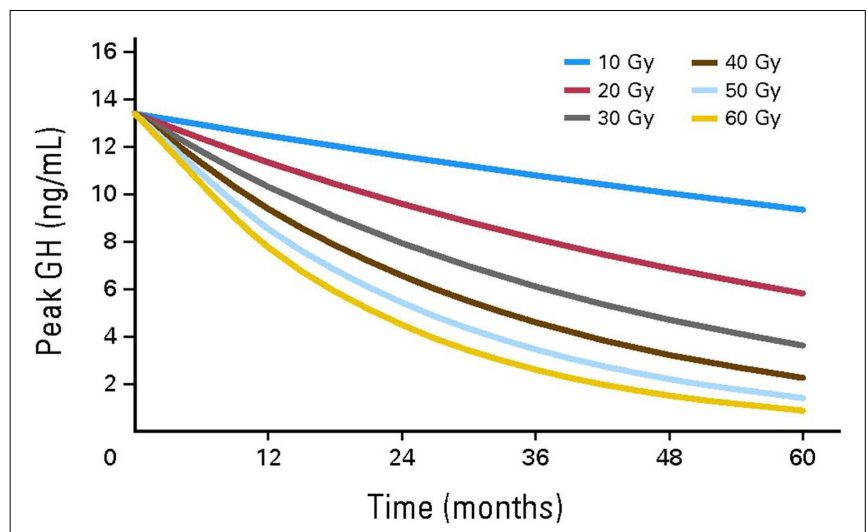

FIGURE 2 | Growth hormone secretion after hypothalamic/pituitary exposures to radiotherapy. Reproduced with permission from Ref. (13) C2011 by American Society of Clinical Oncology.

prospects by delaying skeletal maturation and allowing a longer time for linear growth (43). This treatment may also act synergistically with $\mathrm{rGH}$ and improve the final adult height of $\mathrm{GH}$-deficient CCS who also have CPP (43). Determining the best time to discontinue GnRH agonist therapy even in children with idiopathic CPP can be challenging and requires taking into account multiple factors including chronological age, bone age, target height, psycho-social maturation, and parental preferences. This determination is rendered even more challenging by the possible development over time of permanent LH/FSH deficiency in these patients (44). The use of aromatase inhibitors in order to prolong the delay in closure of growth plates in concert with rGH has been utilized by some clinicians to augment the height outcomes of CCS (45). Data remain inconclusive as to whether or not aromatase inhibitors improve adult height and many pediatric endocrinologists consider their use to be experimental.

\section{LH/FSH deficiency}

The deficiency in LH/FSH, also referred to as hypogonadotropic hypogonadism, can result in delayed or arrested pubertal development during childhood. The post-pubertal male and female with LH/FSH deficiency may present with androgen insufficiency symptoms and secondary amenorrhea, respectively. LH/FSH deficiency can occur after tumor and/or surgery related damage or after doses of radiotherapy to the hypothalamic-pituitary area $>30$ Gy $(36,46,47)$. Female CCS diagnosed after the age of 10 years and who received doses $>50 \mathrm{~Gy}$ are at high risk for delayed menarche (36). Deficiency in LH/FSH may also occur in the context of ipilimumab-induced auto-immune hypophysitis, as detailed in Section "Corticotropin Deficiency" (7). Replacement is warranted for the development and maintenance of secondary sex characteristic, optimal bone mass accrual, and body composition. Sex steroids also play a pivotal role in the metabolism of lipids and carbohydrates (48).

\section{CORTICOTROPIN DEFICIENCY}

Corticotropin (ACTH) deficiency, also known as central adrenal insufficiency, can occur in CCS following tumor and/or surgery related damage or after the exposure of the hypothalamus/pituitary to radiotherapy doses $\geq 30$ Gy (49). Hudson et al. identified disorders of the hypothalamic-pituitary-adrenal axis in $13.8 \%$ of CCS exposed to cranial radiotherapy (2). In a study of children with embryonal brain tumors treated with radiotherapy, the 4-year cumulative incidence of ACTH deficiency was $38 \pm 6 \%$ and there was no significant difference in those patients who received irradiation of $>42$ and $<42 \mathrm{~Gy}$ (50). The incidence of ACTH deficiency in patients receiving TBI as part of preconditioning of BMT has been reported at 6\% (51) ACTH deficiency was documented in $60 \%(n=50)$ of patients receiving BMT for malignant and non-malignant reasons. It was more likely to occur in patients who had been transplanted $<1$ year prior to testing and all the subjects who were diagnosed were asymptomatic (15). The clustering of ACTH deficiency cases within a year of transplant in this study suggests that a large proportion of patients experience transient forms of this condition as a result of their exposure to high-dose glucocorticoids. More recently, ACTH deficiency has been associated with the use of imatinib, a TKI with $48 \%$ of individuals diagnosed 3-71 months following the exposure (52). Ipilimumab, an immune system modulator can cause auto-immune hypophysitis with ensuing panhypopituitarism, especially at doses $>3 \mathrm{mg} / \mathrm{kg}$ with a reported prevalence of $4.9-17 \%(7,53,54)$. The onset of hypophysitis may not occur until 6 weeks after therapy and affected individuals may require $2-5$ years of glucocorticoid therapy (55). Future investigations are needed to determine when and for how long CCS treated with these agents should be tested. If patients are deemed insufficient, the chronicity of the insufficiency should also be studied.

Symptoms of ACTH deficiency include fatigue, weakness, nausea, vomiting, anorexia, and abdominal cramping. When exposed to a severe illness, patients with ACTH deficiency may develop life threatening complications including hypoglycemia related seizures and hypotensive shock. Untreated ACTH deficiency may be associated with decreased free water clearance and hyponatremia; replacement with hydrocortisone in such instances, especially in post-surgical patients, may unmask co-existent central diabetes insipidus. A screening cortisol level, collected at 8 a.m. that is $\geq 10 \mathrm{mcg} / \mathrm{dl}$ is reassuring and against the presence of ACTH deficiency; a value $\leq 5 \mathrm{mcg} / \mathrm{dl}$ at 8 a.m. should in contrast raise high suspicions regarding this diagnosis. Definitive testing includes insulin tolerance, low dose cosyntropin or metyrapone stimulation tests. A peak cortisol value $<18 \mu \mathrm{g} / \mathrm{dl}$ following low dose (1 microgram) cosyntropin is the most commonly used diagnostic criterion (56). The treatment of ACTH deficiency relies on replacement therapy with hydrocortisone and patient and family education regarding stress dosing during times of illness.

\section{TSH DEFICIENCY}

Thyroid stimulating hormone deficiency, also known as central hypothyroidism, is rarely reported in CCS. It can occur as a result of tumor and/or surgery related damage or after hypothala$\mathrm{mic} /$ pituitary exposure to radiotherapy doses $\geq 30 \mathrm{~Gy}(44,50,57$, $58)$. One CCS study detected TSH deficiency in $6 \%(n=71)$ of childhood brain tumor survivors (59). Deficiency in TSH may also occur in the context of ipilimumab-induced auto-immune hypophysitis, as detailed in Section "Corticotropin Deficiency" (7). 
Hypothyroidism is associated with poor linear growth, delayed bone age, and disturbances in pubertal timing during childhood. It can also cause fatigue, fluid retention, constipation, cold intolerance, proximal muscle weakness, and depression. A serum free T4 (FT4) below normal in conjunction with a low or normal serum TSH is characteristic of TSH deficiency. Levothyroxine is used to treat this form of hypothyroidism with doses are adjusted to maintain FT4 values within mid to high normal ranges (60). In contrast to primary hypothyroidism $(\mathrm{PH})$, serum TSH values are not helpful in the monitoring of this condition, as they are expected to remain low even after inadequate replacement with levothyroxine.

\section{HYPERPROLACTINEMIA}

Prolactin production by the pituitary gland is controlled by the hypothalamus, with a predominantly inhibitory tone due to dopaminergic input. Disruptions of hypothalamic-pituitary connections due to tumor growth, surgery, or doses of radiotherapy $>30-50$ Gy can result in hyperprolactinemia because of the loss of hypothalamic inhibition on prolactin secretion $(44,61,62)$. Patients with hyperprolactinemia can present with galactorrhea. Furthermore, elevated prolactin levels may suppress LH and FSH production and cause hypogonadism. Nevertheless, hyperprolactinemia in CCS tends to remain asymptomatic, especially in a patient population where individuals are concurrently at risk of gonadotropin deficiency and primary gonadal failure because of their cancer treatment exposures (62).

\section{CENTRAL DIABETES INSIPIDUS}

Central diabetes insipidus is the clinical manifestation of the deficit in secretion and release of the anti-diuretic hormone $(\mathrm{ADH})$. Hypothalamic neurons are responsible of the production of $\mathrm{ADH}$; the latter is carried by axonal transport to the posterior pituitary from which it is released into the circulation. The deficiency in $\mathrm{ADH}$ impairs the affected individual's ability to concentrate urine with ensuing polyuria, polydipsia, and dehydration when access to free water is compromised. Central diabetes insipidus can be a mode of revelation of childhood brain malignancies such as dysgerminomas or hypophyseal non-Hodgkin's lymphomas $(63,64)$. In these instances, it can initially be isolated and as the tumoral infiltration worsens additional pituitary functions become deficient (64). More commonly, however, diabetes insipidus occurs in the context of pan-hypopituitarism due to the presence of a tumor in close proximity to the sellar region or as a consequence of surgical procedures aimed at removing it. Central diabetes insipidus does not occur as a late effect of cranial radiotherapy and is hence rarely discussed in the literature dedicated to CCS (65). Central diabetes insipidus does not seem to be associated with the use of ipilimumab (7). The management of central diabetes insipidus consists of replacement therapy using desmopressin with close monitoring of fluid intake and urine output in order to avoid overtreatment and ensuing hyponatremia and seizures. Significant shifts in replacement needs are noted in the post-operative patient, mandating close monitoring in the inpatient setting until stabilization is achieved $(66,67)$. This was well characterized following neurosurgical interventions on sellar/supra sellar tumors such as craniophayngioma with the classical description of a triple phase response consisting of a first phase of transient diabetes insipidus lasting for up to 2 days, followed by an anti-diuretic phase of 1-2 weeks before the onset of permanent diabetes insipidus (67). Patients with altered thirst sensation are more easily managed with the determination of a fixed daily fluid requirement in addition to a fixed dose of desmopressin in order to avoid significant fluctuations in their hydration status (66).

\section{DISORDERS OF THE THYROID}

The radiosensitive nature of the thyroid gland predisposes it to dysfunctions including hypothyroidism, hyperthyroidism, nodules, and cancer (Table 2). Hudson et al. identified thyroid disorders in up to $66.4 \%$ of CCS exposed to neck radiotherapy (2). Thyroid dysfunction has been attributed to multiple cancer therapies including radiotherapy with direct or scatter exposure of the neck, TKI, 131 I-Metaidobenzylguanidine ([131I] MIBG), retinoid $\mathrm{X}$ receptor agonist autoantibodies, angiogenesis inhibitor thalidomide, and interferon- $\alpha(68-70)$.

\section{PRIMARY HYPOTHYROIDISM}

Primary hypothyroidism is the most common thyroid abnormality in CCS. In a study by Armstrong et al., the relative risk of $\mathrm{PH}$ in CCS was 17.1 when compared to sibling controls (70). The study also documented that up to $50 \%$ Hodgkin lymphoma patients receiving $>45$ Gy developed hypothyroidism within 5-years (70). Female sex and older age at diagnosis were also associated with an increased incidence of hypothyroidism. The risk of $\mathrm{PH}$ has primarily been attributed to direct or scatter radiation of the neck including cranio-spinal radiotherapy as well as TBI for cytoreduction before HSCT $(50,58,59,71)$. Subclinical or compensated $\mathrm{PH}$ is more commonly diagnosed than overt $\mathrm{PH}$ in the context of low dose radiotherapy and HSCT, with some patients experiencing spontaneous recovery (58). Chemotherapy alone has not been traditionally associated with $\mathrm{PH}$. However, TKIs such as sorafenib, sunitinib, and imatinib have been noted to cause thyroid dysfunction (72-74). Hypothyroidism during treatment with sunitinib occurred in $7-85 \%$ of patients $(72,73)$. The pathophysiology of TKI causing PH remains elusive; it may be secondary to destruction of the thyroid gland, impairments of thyroid hormone transport or metabolism, or reduced TSH clearance (72). $\mathrm{PH}$ was documented in 13 out 16 CCS of neuroblastoma treated with [131I] MIBG in a long-term follow-up study over a period of 15.5 years (11.2-20.2) (69).

Extended surveillance for thyroid dysfunction is crucial as hypothyroidism in CCS exposed to radiotherapy and radio-labeled agents may occur decades later. The clinical presentation of $\mathrm{PH}$ is similar to central hypothyroidism in CCS; however, biochemically they differ. The labs in PH include an elevated plasma TSH level with normal or low free T4; both values are used in monitoring replacement using levothyroxine at substitutive doses.

\section{HYPERTHYROIDISM}

Hyperthyroidism was diagnosed in up to $5 \%$ of survivors in a report by Armstrong et al., a rate that was 8 times greater than in sibling controls (70). Overt hyperthyroidism albeit rare has been reported in CCS after hematopoietic stem-cell transplant (HSCT) (75-77). The occurrence of hyperthyroidism may be 
Table 2 | Peripheral endocrinopathies.

\begin{tabular}{|c|c|c|c|c|c|}
\hline Function & Complication & $\begin{array}{l}\text { Therapy-related } \\
\text { risks }\end{array}$ & $\begin{array}{l}\text { Relationship to time, dose to gland, } \\
\text { or organ when applicable }\end{array}$ & Evaluation/labs & Intervention \\
\hline \multirow[t]{5}{*}{ Thyroid } & \multirow[t]{2}{*}{$\begin{array}{l}\text { Primary } \\
\text { hypothyroidism }\end{array}$} & Neck irradiation & $\begin{array}{l}\text { Risk increases with dose and time after } \\
\text { exposure }\end{array}$ & \multirow[t]{2}{*}{ TSH, FT4 } & \multirow[t]{2}{*}{ Levothyroxine } \\
\hline & & I131 labeled agents & MIBG for neuroblastoma & & \\
\hline & Hyperthyroidism & Neck irradiation & Doses $\geq 35 \mathrm{~Gy}$ & TSH, FT4, T3 & $\begin{array}{l}\text { Dependent on clinical } \\
\text { course }\end{array}$ \\
\hline & $\begin{array}{l}\text { Auto-immune } \\
\text { hypothyroidism }\end{array}$ & HSCT & Transfer of auto-immunity from donor & TSH, FT4 & Levothyroxine \\
\hline & Thyroid neoplasms & Neck irradiation & $\begin{array}{l}\text { Doses } 20-29 \text { Gy } \\
\text { Age }<10 \text { at exposure } \\
\text { Females at higher risk }\end{array}$ & $\begin{array}{l}\text { Yearly palpation of neck } \\
\text { Thyroid US } \\
\text { US guided FNAB }\end{array}$ & Per etiology \\
\hline $\begin{array}{l}\text { Gonadal } \\
\text { disorders } \\
\text { male }\end{array}$ & $\begin{array}{l}\text { Germ cell } \\
\text { dysfunction }\end{array}$ & $\begin{array}{l}\text { Testicular irradiation } \\
\text { Alkylating agents }\end{array}$ & $\begin{array}{l}\text { Possible } \geq 0.15 \mathrm{~Gy} \\
\text { High risk } \geq 2 \mathrm{~Gy} \\
\text { Cyclophosphamide dose } \geq 7.5 \mathrm{gram} / \mathrm{m}^{2 a} \\
\text { MOPP } \geq 3 \text { cycles } \\
\text { Busulfan } \geq 600 \mathrm{mg} / \mathrm{m}^{2 a} \\
\text { Ifosfamide } \geq 60 \mathrm{~g} / \mathrm{m}^{2 a} \\
\text { Any alkylating agent in combination with } \\
\text { radiotherapy to the testes }\end{array}$ & $\begin{array}{l}\text { Baseline LH, FSH, } \\
\text { inhibin B } \\
\text { Adults: semen analysis }\end{array}$ & Sperm banking \\
\hline $\begin{array}{l}\text { Gonadal } \\
\text { disorders } \\
\text { female }\end{array}$ & Ovarian failure & $\begin{array}{l}\text { Abdominopelvic } \\
\text { irradiation } \\
\text { Alkylating agents }\end{array}$ & $\begin{array}{l}\text { Acute ovarian failure doses } \geq 20 \mathrm{~Gy} \\
\text { Premature menopause/infertility at } \\
\text { lower doses } \\
\text { Higher risk at older age } \\
\text { Higher risk at older age }\end{array}$ & $\begin{array}{l}\text { Baseline LH, FSH, } \\
\text { estradiol } \\
\text { Pubertal females-AMH }\end{array}$ & $\begin{array}{l}\text { Induction of puberty with } \\
\text { estradiol } \\
\text { Hormone replacement } \\
\text { therapy } \\
\text { Mature oocyte } \\
\text { cryopreservation }\end{array}$ \\
\hline \multirow[t]{2}{*}{ Metabolic } & $\begin{array}{l}\text { Obesity overweight } \\
\text { Insulin resistance }\end{array}$ & Surgery & Hypothalamic injury/central obesity & Waist to Hip Ratio & \multirow{2}{*}{$\begin{array}{l}\text { Lifestyle modifications - } \\
\text { diet, physical activity } \\
\text { Per etiology }\end{array}$} \\
\hline & $\begin{array}{l}\text { Metabolic syndrome } \\
\text { Diabetes mellitus }\end{array}$ & Radiotherapy & $\begin{array}{l}\text { Cranial radiotherapy abdominal radiation } \\
\text { TBI }\end{array}$ & $\begin{array}{l}\text { Fasting: glucose, lipids, } \\
\text { insulin, HbA1c } \\
\text { Oral glucose tolerance } \\
\text { if fasting test abnormal }\end{array}$ & \\
\hline
\end{tabular}

TBI, total-body irradiation; TSH, thyroid stimulating hormone; AM, morning sample; $L H$, luteinizing hormone; FSH, follicle-stimulating hormone; FNAB, ultrasound guided fine needle; aspiration biopsy; TKI, tyrosine kinase inhibitors; $A M H$, anti-Mullerian hormone; BMD, bone mineral density.

${ }^{a}$ Cumulative dose; source: long-term follow-up guidelines for survivors of childhood, adolescent, and young adult cancers-Version 3.0-Oct 2008. Children's Oncology Group - www.survivorshipguidelines.org.

more common shortly after HSCT with Jung et al. reporting a prevalence of $4.5 \%$ in the first 3 months following transplant (77). Lower prevalence values $(0.7-2 \%)$ have been reported in studies incorporating long-term follow in the pediatric HSCT population $(75,76)$.

\section{AUTOIMMUNE INDUCED THYROID DISEASE}

Positive thyroid autoantibodies have been reported in cases of hypothyroidism and hyperthyroidism in CCS of allogeneic HSCT $(78,79)$. It has been presumed to be related to the transfer of auto-immunity from the stem-cell donor to the HSCT recipient. 
However, the presence of thyroid antibodies does not necessarily lead to progression to hypothyroidism in the context of HSCT (80). Auto-immune thyroiditis may exacerbate the thyroid toxicity of certain, but not all, TKI $(72,81)$. Autoimmune and non-autoimmune thyroiditis are also well established toxicities of interferon- $\alpha$, a human recombinant cytokine used in the treatment of some solid tumors and hematologic malignancies (82). Newer anticancer agents such as the monoclonal antibodies have also been associated with rare cases of auto-immune hypothyroidism and transient hyperthyroidism. The incidences of ipilimumab-induced auto-immune hypothyroidism in small case reports have been $0-2,7$, and $19 \%$ in patients receiving standard doses, high doses, and combination therapy with bevacizumab, respectively (82).

\section{THYROID NEOPLASMS}

Second thyroid neoplasms may occur later than two decades after the diagnosis of the primary cancer in CCS $(83,84)$. Armstrong et al. conveyed that 20 years after diagnosis, the risk of having a thyroid nodule in CCS after exposure to neck irradiation was $20 \%$, which is 27 times higher than the sibling population (70). The association between the development of thyroid cancer and direct or scatter radiation of the neck is well known (85). In a large cohort of 12,575 CCS, 111 cases of second primary cancers were pathologically confirmed in patients who had received radiotherapy (86). The most common second primary cancer was papillary thyroid carcinoma and the risk was highest in patients who had received $\leq 20 \mathrm{~Gy}$, were of female and of a young age $(<10$ years) at the time of diagnosis of the primary cancer (86). Hodgkin lymphoma is the primary cancer most commonly associated with thyroid cancer. The cumulative incidence of thyroid cancer was $2.3 \%(95 \% \mathrm{CI}, 1.7-3.1)$ in this population (83). A recent report by Veiga et al. suggested that alkylating agents in conjunction with $<20$ Gy of irradiation can increase the incidence of thyroid neoplasm by 2.4 (95\% CI, 1.3-4.5; $p=0.002$ ) (83). Radiolabeled agents such as 131I MIBG used in the treatment of neuroblastomas have also been associated with the development of papillary thyroid cancer (68).

The currently recommended screening modality for thyroid cancer in CCS at risk is the yearly clinical examination of the neck by an experienced provider. There is significant disagreement regarding the use of thyroid ultrasound for the purposes of screening in the absence of clinical symptoms, because of the high probability of finding abnormal results leading to higher rates of diagnostic procedures and unnecessary anxiety to patients and their families; the yield in identifying malignant nodules with ultrasonography is indeed low, even in survivors of Hodgkin lymphoma (87-90). Kovalchik et al. recently validated an absolute risk prediction model (AUC 0.80, 95\% CI), screening for thyroid cancer in CCS. The model was based on sex, age $<15$ years at primary cancer diagnosis, history of thyroid nodule, radiotherapy to the neck, and exposure to alkylating agents (91). The diagnosis of second primary thyroid cancer in CCS relies on the presence of a positive result on a fine needle aspiration biopsy of a suspected nodule; the treatment approach and prognosis are identical to thyroid cancer cases diagnosed in the general population (87).

\section{DISORDERS OF THE GONADS \\ MALES}

The testes have two functional compartments, a reproductive compartment and an endocrine compartment (Table 2). The reproductive compartment consists of germ cells and the Sertoli cells that support them. The endocrine compartment encompasses the Leydig cells, which are responsible for producing testosterone. The two compartments are affected differently by cancer therapies and understanding this dichotomy in testicular function is imperative in counseling male CCS in regards to their risk of gonadal dysfunction.

\section{Leydig cell dysfunction}

Hypogonadism after chemotherapy exposure alone is rare (92, 93). However, high doses of alkylating agents, such as cyclophosphamide can cause low testosterone $(94,95)$. There are also case reports of broad acting kinase inhibitors causing low testosterone and gynecomastia (96). Leydig cell dysfunction as a result of testicular irradiation is dependent on the age of the exposure and the dose of irradiation. Pre-pubertal males receiving doses $>24 \mathrm{~Gy}$ are at high risk for hypogonadism, whereas pubertal males are at risk when exposed to $>33$ Gy (97-99). An elevated LH and a low normal morning testosterone define subclinical hypogonadism, and can be attributed to moderate doses of alkylating agent and low dose of testicular irradiation ( $<20 \mathrm{~Gy})$; however, subclinical hypogonadism rarely requires exogenous testosterone replacement therapy (99-101). At risk, CCS should be followed closely for signs and biochemical evidence of hypogonadism that warrant replacement therapy during pubertal years and adulthood.

\section{Germ cell dysfunction}

Germ cells are more sensitive to testicular irradiation and chemotherapy than Leydig cells. Chemotherapy agents associated with germ cell dysfunction include cyclophosphamide, procarbazine, ifosfamide, busulfan, melphalan, and cisplatin $(99,102)$. Green et al. reported germ cell dysfunction with subsequent azospermia in $38.2 \%(n=275)$ males exposed to chemotherapy and/or testicular irradiation (103). Small testicular volume, elevated FSH, and low inhibin B levels are associated with poor fertility prognosis in males; however, these clinical and biochemical findings lack sensitivity and specificity in male CCS. Males exposed to gonadotoxic agents may recover germ cell function and it is recommended that they have semen analyses in order to determine fertility status $(103,104)$.

Sperm cryopreservation is recommended in cancer patients prior to therapy with gonodotoxic agents. In pre-pubertal males, an approach combining testicular tissue extraction, spermatogonial stem-cell preservation, and later transplantation of decontaminated (non-malignant) cells has been proposed but remains experimental $(99,105,106)$.

\section{FEMALES}

The ovaries do not replicate the functional dichotomy (distinct endocrine and reproductive compartments) observed in the testes. The female ovarian follicle is responsible for estrogen production and oocyte maturation, and both functions are simultaneously 
affected by gonadal failure. The extent of ovarian damage and subsequent residual function do not solely depend on the intensity of the cancer treatments received by the patient. These also depend on the number of viable follicles, or "ovarian reserve," at the time of the exposure. Patients whose viable follicles were depleted during therapy do not experience a recovery of their ovarian function after the completion of cancer treatments and are diagnosed with acute ovarian insufficiency (107). A subset of individuals, with a less severe but nevertheless significant depletion of their ovarian reserve, will experience a resumption of pubertal development or menstrual cycles in the few years following the completion of cancer therapy only to be diagnosed several years later with premature menopause, which is defined as ovarian failure prior to the age of 40 years (108). Given naturally declining numbers of follicles during a woman's lifespan, ovarian reserve and, consequently, vulnerability to damage from gonadotoxic agents, are particularly dependent on chronological age at the time of exposure to cancer treatments $(107,108)$. Cancer treatments associated with ovarian toxicity include abdominopelvic irradiation (API) and chemotherapy agents such as cyclophosphamide, procarbazine, busulfan, melphalan, and thiotepa (107-110). Chemotherapy is less toxic to the ovaries of pre-pubertal females in comparison to pubertal and adult females $(107,111-113)$. The ovarian toxicity of API is age and dose dependent, irradiation doses $>20$ Gy in female, CCS $>13$ years old, and TBI in CCS $>10$-years is correlated with ovarian insufficiency $(107,114,115)$. A study of an AML cohort treated with chemotherapy alone (anthracyclines and cytarabine) demonstrated that menarche occurred at the mean age of 13.1 years and fertility rates were similar to their siblings (92). Even in the absence of exposure to API and despite the occurrence of menarche at a normal age, CCS were nevertheless shown to have a decreased reproductive capacity in comparison to healthy controls in another report (113). The risk of premature menopause was 8 and $0.8 \%$ $(\mathrm{RR}=13.21,95 \% \mathrm{CI}=3.26-53.51 ; p<0.001)$ in CCS and siblings, respectively (108). The cumulative incidence of premature menopause was highest among CCS exposed to both alkylating agents and API (108). Evidence of ovarian insufficiency includes elevated gonadotropins, low anti-mullerian hormone (AMH) levels, and reduced mean ovarian volume (113). AMH is an acceptable marker of ovarian follicular reserve in female CCS, and low levels are indicative of declining ovarian function (116-119). Despite declining ovarian reserve in CCS, some survivors have successful pregnancies, with live birth rates of 63-73\% (119-121).

Young CCS with ovarian failure may experience poor linear growth and poor bone mineralization. Older hypo-gonadal females can develop menopausal symptoms and are at risk for osteoporosis and cardiovascular disease $(122,123)$. Sex hormone replacement therapy is warranted in female CCS with ovarian failure. The use of cryopreserved ovarian tissue from pre-pubertal females carries the risk of re-seeding malignant cells and is considered experimental; by contrast, mature oocyte cryopreservation is no longer considered experimental and may represent a viable option for young pubertal females prior to gonadotoxic therapies (124). The availability of this technique, along with better ways of assessing ovarian reserve in females at risk of premature menopause may improve fertility prospects in the CCS population.

\section{BONE HEALTH RELATED COMPLICATIONS}

Childhood cancer survivors have an increased risk of poor bone health and decreased BMD (Table 2). Contributing factors include the primary cancer (increased osteoclast stimulation in hematological malignancies), treatment exposures, and concurrent hormone deficiencies (125). CCS treated with glucocorticoids and methotrexate or exposed to cranio-spinal radiotherapy, especially receiving $>24$ Gy of cranial irradiation are susceptible to decreased $\operatorname{BMD}(125,126)$. The association between central nervous system exposures to radiotherapy and low BMD is likely due to radiation related endocrinopathies (deficiencies in GH and/or sex steroids in particular) (126). Lower BMD can be observed prior to cancer therapies because of the effect of the primary illness itself on bone (127). In a recent report on childhood ALL, the 3-year cumulative symptomatic fracture risk was $17.8 \%(n=399)$. Fractures were more likely to occur during therapy than during follow up (127). The decline in BMD did not correlate with fracture risk in this study as well as in a report on survivors of osteosarcoma (127, 128). Recent studies have provided further reassurance regarding the continued recovery of BMD after the completion of therapy, a progress that continues, even in older individuals followed through adulthood $(126,129)$.

Optimizing bone health in CCS includes hormone replacement therapy for those with GHD, hypogonadism, and vitamin D deficiency. It is also recommended that survivors receive adequate nutritional calcium, participate in weight bearing activities, and avoid smoking $(125,128)$.

\section{OVERWEIGHT, OBESITY, AND DISORDERS OF GLUCOSE HOMEOSTASIS}

Obesity is a recognized public health challenge with far reaching consequences on overall states of health in the general population $(130,131)$ (Table 2). The prevalence of obesity and metabolic syndrome in the overall CCS population seems to be comparable to that observed in the general population $(2,130,132)$. Hudson et al. demonstrated the prevalence of obesity, hypertension, dyslipidemia, and diabetes was 36.5, 22.6, 50.9, and 5.9\%, respectively, in a cohort of CCS followed for 26.3 years after diagnosis (2). Nevertheless, survivors of ALL and brain tumors have significantly higher risks of obesity and overweight (133). Additional risk factors include female sex, doses of cranial radiotherapy $>20 \mathrm{~Gy}$, age at exposure <4-years old, and GHD $(134,135)$. CCS with a history of brain tumor development, radiotherapy, or surgery within the hypothalamus or near the sellar region are at risk of developing a particularly severe form of obesity characterized by hyperphagia and rapid weight gain, and which is sometimes referred to as "central" or "hypothalamic" obesity $(136,137)$. In these patients with significant hypothalamic injury, increased parasympathetic tone and ensuing hyperinsulinemia (the latter promoting fat storage) have been suggested as possible causes for this phenomenon (136, 137). Treatment approaches for this particular type of obesity have included octreotide and dextroamphetamine $(137,138)$. In a randomized, double-blind placebo-controlled study of 18 individuals with hypothalamic obesity, octreotide allowed the stabilization of BMI with lower rates of weight gain and lower insulin secretion over a treatment period of 6 months (137). The use of dextroamphetamine in five children with hypothalamic obesity allowed the 
stabilization of BMI over a period of 24 months (138). The small numbers of patients enrolled in these studies with limited longterm follow-up data to support sustainable efficacy as well as the cost and possible side effects of the medications used in these reports have hindered the wider adoption of such treatment strategies. CCS were also shown to have a higher risk of diabetes mellitus, especially following exposure to TBI, abdominal radiotherapy, and alkylating agents $(139,140)$. Further research is needed in order to understand the mechanism by which such treatments leave lasting impacts on metabolism and glucose homeostasis as a preamble in optimizing the management of these disorders.

\section{SUMMARY}

Endocrine complications are common in CCS. Healthcare providers need to be aware of the lifelong endocrinopathies associated with treatment exposures. Further research is needed in order to improve risk prediction and develop patient centered screening strategies as the early diagnosis of endocrine disorders and timely treatment of these complications can improve overall states of health and the quality of life of individuals belonging to this vulnerable population.

\section{REFERENCES}

1. Ward E, Desantis C, Robbins A, Kohler B, Jemal A. Childhood and adolescent cancer statistics, 2014. CA Cancer J Clin (2014) 64:83-103. doi:10.3322/caac. 21219

2. Hudson MM, Ness KK, Gurney JG, Mulrooney DA, Chemaitilly W, Krull KR, et al. Clinical ascertainment of health outcomes among adults treated for childhood cancer. JAMA (2013) 309:2371-81. doi:10.1001/jama.2013.6296

3. de Fine Licht S, Winther JF, Gudmundsdottir T, Holmqvist AS, Bonnesen TG, Asdahl PH, et al. Hospital contacts for endocrine disorders in Adult Life after Childhood Cancer in Scandinavia (ALiCCS): a population-based cohort study. Lancet (2014) 383:1981-9. doi:10.1016/S0140-6736(13)62564-7

4. Brignardello E, Felicetti F, Castiglione A, Chiabotto P, Corrias A, Fagioli F, et al. Endocrine health conditions in adult survivors of childhood cancer: the need for specialized adult-focused follow-up clinics. Eur J Endocrinol (2013) 168:465-72. doi:10.1530/EJE-12-1043

5. Lodish MB. Clinical review: kinase inhibitors: adverse effects related to the endocrine system. J Clin Endocrinol Metab (2013) 98:1333-42. doi:10.1210/jc. 2012-4085

6. Kong YC, Flynn JC. Opportunistic autoimmune disorders potentiated by immune-checkpoint inhibitors anti-CTLA-4 and anti-PD-1. Front Immunol (2014) 5:206. doi:10.3389/fimmu.2014.00206

7. Corsello SM, Barnabei A, Marchetti P, De Vecchis L, Salvatori R, Torino F. Endocrine side effects induced by immune checkpoint inhibitors. J Clin Endocrinol Metab (2013) 98:1361-75. doi:10.1210/jc.2012-4075

8. Chow EJ, Friedman DL, Yasui Y, Whitton JA, Stovall M, Robison LL, et al. Decreased adult height in survivors of childhood acute lymphoblastic leukemia: a report from the childhood cancer survivor study. J Pediatr (2007) 150(370-5):5e1. doi:10.1016/j.jpeds.2006.11.036

9. Chow EJ, Liu W, Srivastava K, Leisenring WM, Hayashi RJ, Sklar CA, et al. Differential effects of radiotherapy on growth and endocrine function among acute leukemia survivors: a childhood cancer survivor study report. Pediatr Blood Cancer (2013) 60:110-5. doi:10.1002/pbc.24198

10. Knijnenburg SL, Mulder RL, Schouten-Van Meeteren AY, Bökenkamp A, Blufpand $\mathrm{H}$, van Dulmen-den Broeder E, et al. Early and late renal adverse effects after potentially nephrotoxic treatment for childhood cancer. Cochrane Database Syst Rev (2013) 10:CD008944. doi:10.1002/14651858.CD008944.pub2

11. Xu W, Janss A, Packer RJ, Phillips P, Goldwein J, Moshang T Jr. Endocrine outcome in children with medulloblastoma treated with 18 Gy of craniospinal radiation therapy. Neuro Oncol (2004) 6:113-8. doi:10.1215/ S1152851703000462

12. Clayton PE, Shalet SM. The evolution of spinal growth after irradiation. Clin Oncol (1991) 3:220-2. doi:10.1016/S0936-6555(05)80744-7
13. Merchant TE, Rose SR, Bosley C, Wu S, Xiong X, Lustig RH. Growth hormone secretion after conformal radiation therapy in pediatric patients with localized brain tumors. J Clin Oncol (2011) 29:4776-80. doi:10.1200/JCO.2011.37.9453

14. Rose SR, Schreiber RE, Kearney NS, Lustig RH, Danish RK, Burghen GA, et al. Hypothalamic dysfunction after chemotherapy. J Pediatr Endocrinol Metab (2004) 17:55-66. doi:10.1515/JPEM.2004.17.1.55

15. Gundgurthi A, Garg MK, Nair V, Pakhetra R, Das S, Sharma S, et al. Endocrine complications after busulphan and cyclophosphamide based hematopoietic stem cell transplant: a single tertiary care centre experience. Ind J Endocrinol Metab (2013) 17:855-63. doi:10.4103/2230-8210.117248

16. Bakker B, Oostdijk W, Bresters D, Walenkamp MJ, Vossen JM, Wit JM. Disturbances of growth and endocrine function after busulphan-based conditioning for haematopoietic stem cell transplantation during infancy and childhood. Bone Marrow Transplant (2004) 33:1049-56. doi:10.1038/sj.bmt.1704481

17. van den Heijkant S, Hoorweg-Nijman G, Huisman J, Drent M, van der Pal $\mathrm{H}$, Kaspers GJ, et al. Effects of growth hormone therapy on bone mass, metabolic balance, and well-being in young adult survivors of childhood acute lymphoblastic leukemia. J Pediatr Hematol Oncol (2011) 33:e231-8. doi:10.1097/MPH.0b013e31821bbe7a

18. Rastogi MV, Stork L, Druker B, Blasdel C, Nguyen T, Boston BA. Imatinib mesylate causes growth deceleration in pediatric patients with chronic myelogenous leukemia. Pediatr Blood Cancer (2012) 59:840-5. doi:10.1002/pbc.24121

19. Mariani S, Giona F, Basciani S, Brama M, Gnessi L. Low bone density and decreased inhibin-B/FSH ratio in a boy treated with imatinib during puberty. Lancet (2008) 372:111-2. doi:10.1016/S0140-6736(08)61023-5

20. Rosenfield RL, Furlanetto R. Physiologic testosterone or estradiol induction of puberty increases plasma somatomedin-C. J Pediatr (1985) 107:415-7. doi:10.1016/S0022-3476(85)80522-9

21. Iwayama H, Kamijo T, Ueda N. Hyperinsulinemia may promote growth without $\mathrm{GH}$ in children after resection of suprasellar brain tumors. Endocrine (2011) 40:130-3. doi:10.1007/s12020-011-9493-y

22. Sizonenko PC, Clayton PE, Cohen P, Hintz RL, Tanaka T, Laron Z. Diagnosis and management of growth hormone deficiency in childhood and adolescence. Part 1: diagnosis of growth hormone deficiency. Growth Horm IGF Res (2001) 11:137-65. doi:10.1054/ghir.2001.0203

23. Growth Hormone Research Society. Consensus guidelines for the diagnosis and treatment of growth hormone $(\mathrm{GH})$ deficiency in childhood and adolescence: summary statement of the GH Research Society. GH Research Society. J Clin Endocrinol Metab (2000) 85:3990-3. doi:10.1210/jc.85.11.3990

24. Schriock EA, Lustig RH, Rosenthal SM, Kaplan SL, Grumbach MM. Effect of growth hormone $(\mathrm{GH})$-releasing hormone $(\mathrm{GRH})$ on plasma $\mathrm{GH}$ in relation to magnitude and duration of GH deficiency in 26 children and adults with isolated GH deficiency or multiple pituitary hormone deficiencies: evidence for hypothalamic GRH deficiency. J Clin Endocrinol Metab (1984) 58:1043-9.

25. Blijdorp K, van den Heuvel-Eibrink M, Pieters R, Boot A, Sluimer J, van der Lelij AJ, et al. The limited screening value of insulin-like growth factor-I as a marker for alterations in body composition in very long-term adult survivors of childhood cancer. Pediatr Blood Cancer (2012) 59:711-6. doi:10.1002/pbc.24015

26. Chemaitilly W, Robison LL. Safety of growth hormone treatment in patients previously treated for cancer. Endocrinol Metab Clin North Am (2012) 41:785-92. doi:10.1016/j.ecl.2012.07.002

27. Sklar CA, Mertens AC, Mitby P, Occhiogrosso G, Qin J, Heller G, et al. Risk of disease recurrence and second neoplasms in survivors of childhood cancer treated with growth hormone: a report from the childhood cancer survivor study. J Clin Endocrinol Metab (2002) 87:3136-41. doi:10.1210/jcem.87.7.8606

28. Swerdlow AJ, Reddingius RE, Higgins CD, Spoudeas HA, Phipps K, Qiao Z, et al. Growth hormone treatment of children with brain tumors and risk of tumor recurrence. J Clin Endocrinol Metab (2000) 85:4444-9. doi:10.1210/ jcem.85.12.7044

29. Karavitaki N, Warner JT, Marland A, Shine B, Ryan F, Arnold J, et al. GH replacement does not increase the risk of recurrence in patients with craniopharyngioma. Clin Endocrinol (2006) 64:556-60. doi:10.1111/j.1365-2265. 2006.02508.x

30. Ergun-Longmire B, Mertens AC, Mitby P, Qin J, Heller G, Shi W, et al. Growth hormone treatment and risk of second neoplasms in the childhood cancer survivor. J Clin Endocrinol Metab (2006) 91:3494-8. doi:10.1210/jc.2006-0656

31. Woodmansee WW, Zimmermann AG, Child CJ, Rong Q, Erfurth EM, BeckPeccoz P, et al. Incidence of second neoplasm in childhood cancer survivors 
treated with GH: an analysis of GeNeSIS and HypoCCS. Eur J Endocrinol (2013) 168:565-73. doi:10.1530/EJE-12-0967

32. Patterson BC, Chen Y, Sklar CA, Neglia J, Yasui Y, Mertens A, et al. Growth hormone exposure as a risk factor for the development of subsequent neoplasms of the central nervous system: a report from the Childhood Cancer Survivor Study. J Clin Endocrinol Metab (2014) 99:2030-7. doi:10.1210/jc.2013-4159

33. Follin C, Thilen U, Ahren B, Erfurth EM. Improvement in cardiac systolic function and reduced prevalence of metabolic syndrome after two years of growth hormone $(\mathrm{GH})$ treatment in GH-deficient adult survivors of childhood-onset acute lymphoblastic leukemia. J Clin Endocrinol Metab (2006) 91:1872-5. doi:10.1210/jc.2005-2298

34. Muir A. Precocious puberty. Pediatr Rev (2006) 27:373-81. doi:10.1542/pir. 27-10-373

35. Partsch CJ, Sippell WG. Treatment of central precocious puberty. Best Pract Res Clin Endocrinol Metab (2002) 16:165-89. doi:10.1053/beem.2002.0188

36. Armstrong GT, Whitton JA, Gajjar A, Kun LE, Chow EJ, Stovall M, et al. Abnormal timing of menarche in survivors of central nervous system tumors: a report from the childhood cancer survivor study. Cancer (2009) 115:2562-70. doi:10.1002/cncr.24294

37. Oberfield SE, Soranno D, Nirenberg A, Heller G, Allen JC, David R, et al. Age at onset of puberty following high-dose central nervous system radiation therapy. Arch Pediatr Adolesc Med (1996) 150:589-92. doi:10.1001/archpedi.1996. 02170310023003

38. Carel JC, Lahlou N, Roger M, Chaussain JL. Precocious puberty and statural growth. Hum Reprod Update (2004) 10:135-47. doi:10.1093/humupd/dmh012

39. Uruena M, Stanhope R, Chessells JM, Leiper AD. Impaired pubertal growth in acute lymphoblastic leukaemia. Arch Dis Child (1991) 66:1403-7. doi:10.1136/ adc.66.12.1403

40. Lee PA. Central precocious puberty. An overview of diagnosis, treatment, and outcome. Endocrinol Metab Clin North Am (1999) 28:901-18. doi:10.1016/ S0889-8529(05)70108-0

41. Greulich WW, Pyle SI. Radiographic Atlas of Skeletal Development of the Hand and Wrist. 2nd ed. Stanford, CA: Stanford University Press (1959).

42. Haber HP, Wollmann HA, Ranke MB. Pelvic ultrasonography: early differentiation between isolated premature thelarche and central precocious puberty. Eur J Pediatr (1995) 154:182-6. doi:10.1007/BF01954267

43. Gleeson HK, Stoeter R, Ogilvy-Stuart AL, Gattamaneni HR, Brennan BM, Shalet SM. Improvements in final height over 25 years in growth hormone (GH)-deficient childhood survivors of brain tumors receiving GH replacement. J Clin Endocrinol Metab (2003) 88:3682-9. doi:10.1210/jc.2003-030366

44. Fernandez A, Brada M, Zabuliene L, Karavitaki N, Wass JA. Radiation-induced hypopituitarism. Endocr Relat Cancer (2009) 16:733-72. doi:10.1677/ERC-080231

45. Stephen MD, Zage PE, Waguespack SG. Gonadotropin-dependent precocious puberty: neoplastic causes and endocrine considerations. Int J Pediatr Endocrinol (2011) 2011:184502. doi:10.1155/2011/184502

46. Relander T, Cavallin-Stahl E, Garwicz S, Olsson AM, Willen M. Gonadal and sexual function in men treated for childhood cancer. Med Pediatr Oncol (2000) 35:52-63. doi:10.1002/1096-911X(200007)35:1<52::AID-MPO9>3.0.CO;2-Y

47. Byrne J, Fears TR, Mills JL, Zeltzer LK, Sklar C, Meadows AT, et al. Fertility of long-term male survivors of acute lymphoblastic leukemia diagnosed during childhood. Pediatr Blood Cancer (2004) 42:364-72. doi:10.1002/pbc.10449

48. Greenfield DM, Walters SJ, Coleman RE, Hancock BW, Eastell R, Davies HA, et al. Prevalence and consequences of androgen deficiency in young male cancer survivors in a controlled cross-sectional study. J Clin Endocrinol Metab (2007) 92:3476-82. doi:10.1210/jc.2006-2744

49. Rose SR, Danish RK, Kearney NS, Schreiber RE, Lustig RH, Burghen GA, et al. ACTH deficiency in childhood cancer survivors. Pediatr Blood Cancer (2005) 45:808-13. doi:10.1002/pbc.20327

50. Laughton SJ, Merchant TE, Sklar CA, Kun LE, Fouladi M, Broniscer A, et al. Endocrine outcomes for children with embryonal brain tumors after riskadapted craniospinal and conformal primary-site irradiation and high-dose chemotherapy with stem-cell rescue on the SJMB-96 trial. J Clin Oncol (2008) 26:1112-8. doi:10.1200/JCO.2008.13.5293

51. Ogilvy-Stuart AL, Clark DJ, Wallace WH, Gibson BE, Stevens RF, Shalet SM, et al. Endocrine deficit after fractionated total body irradiation. Arch Dis Child (1992) 67:1107-10. doi:10.1136/adc.67.9.1107

52. Bilgir O, Kebapcilar L, Bilgir F, Sarí I, Oner $P$, Karaca B, et al. Is there any relationship between imatinib mesylate medication and hypothalamic-pituitary-adrenal axis dysfunction? Int J Clin Pract (2010) 64:45-50. doi:10.1111/j.1742-1241.2008.01856.x

53. Blansfield JA, Beck KE, Tran K, Yang JC, Hughes MS, Kammula US, et al. Cytotoxic T-lymphocyte-associated antigen-4 blockage can induce autoimmune hypophysitis in patients with metastatic melanoma and renal cancer. J Immunother (2005) 28:593-8. doi:10.1097/01.cji.0000178913. 41256.06

54. Maker AV, Yang JC, Sherry RM, Topalian SL, Kammula US, Royal RE, et al. Intrapatient dose escalation of anti-CTLA-4 antibody in patients with metastatic melanoma. J Immunother (2006) 29:455-63. doi:10.1097/01.cji. 0000208259.73167 .58

55. Weber IS, Dummer R, de Pril V, Lebbe C, Hodi FS, Investigators MDX. Patterns of onset and resolution of immune-related adverse events of special interest with ipilimumab: detailed safety analysis from a phase 3 trial in patients with advanced melanoma. Cancer (2013) 119:1675-82. doi:10.1002/cncr.27969

56. Chrousos GP, Kino T, Charmandari E. Evaluation of the hypothalamicpituitary-adrenal axis function in childhood and adolescence. Neuroimmunomodulation (2009) 16:272-83. doi:10.1159/000216185

57. Rose SR, Lustig RH, Pitukcheewanont P, Broome DC, Burghen GA, Li H, et al. Diagnosis of hidden central hypothyroidism in survivors of childhood cancer. J Clin Endocrinol Metab (1999) 84:4472-9. doi:10.1210/jc.84.12.4472

58. Boulad F, Bromley M, Black P, Heller G, Sarafoglou K, Gillio A, et al. Thyroid dysfunction following bone marrow transplantation using hyperfractionated radiation. Bone Marrow Transplant (1995) 15:71-6.

59. Schmiegelow M, Feldt-Rasmussen U, Rasmussen AK, Poulsen HS, Muller J. A population-based study of thyroid function after radiotherapy and chemotherapy for a childhood brain tumor. J Clin Endocrinol Metab (2003) 88:136-40. doi:10.1210/jc.2002-020380

60. Slawik M, Klawitter B, Meiser E, Schories M, Zwermann O, Borm K, et al. Thyroid hormone replacement for central hypothyroidism: a randomized controlled trial comparing two doses of thyroxine (T4) with a combination of T4 and triiodothyronine. J Clin Endocrinol Metab (2007) 92:4115-22. doi:10.1210/jc.2007-0297

61. Constine LS, Woolf PD, Cann D, Mick G, McCormick K, Raubertas RF, et al. Hypothalamic-pituitary dysfunction after radiation for brain tumors. $N$ Engl J Med (1993) 328:87-94. doi:10.1056/NEJM199301143280203

62. Darzy KH, Shalet SM. Pathophysiology of radiation-induced growth hormone deficiency: efficacy and safety of GH replacement. Growth Horm IGF Res (2006) 16(Suppl A):S30-40. doi:10.1016/j.ghir.2006.03.002

63. Ramelli GP, von der Weid N, Stanga Z, Mullis PE, Buergi U. Suprasellar germinomas in childhood and adolescence: diagnostic pitfalls. J Pediatr Endocrinol Metab (1998) 11:693-7. doi:10.1515/JPEM.1998.11.6.693

64. Silfen ME, Garvin JH Jr, Hays AP, Starkman HS, Aranoff GS, Levine LS, et al. Primary central nervous system lymphoma in childhood presenting as progressive panhypopituitarism. J Pediatr Hematol Oncol (2001) 23:130-3. doi:10.1097/00043426-200102000-00013

65. Spoudeas HA. Growth and endocrine function after chemotherapy and radiotherapy in childhood. Eur J Cancer (2002) 38:1748-59. doi:10.1016/S09598049(02)00169-7

66. Di Iorgi N, Napoli F, Allegri AE, Olivieri I, Bertelli E, Gallizia A, et al. Diabetes insipidus-diagnosis and management. Hormone Res Paediatr (2012) 77:69-84. doi:10.1159/000336333

67. Mishra G, Chandrashekhar SR. Management of diabetes insipidus in children. Ind J Endocrinol Metab (2011) 15:S180-7. doi:10.4103/2230-8210.84858

68. Clement SC, van Eck-Smit BL, van Trotsenburg AS, Kremer LC, Tytgat GA, van Santen HM. Long-term follow-up of the thyroid gland after treatment with 131I-Metaiodobenzylguanidine in children with neuroblastoma: importance of continuous surveillance. Pediatr Blood Cancer (2013) 60:1833-8. doi:10.1002/pbc.24681

69. Haugen BR. Drugs that suppress TSH or cause central hypothyroidism. Best Pract Res Clin Endocrinol Metab (2009) 23:793-800. doi:10.1016/j.beem.2009. 08.003

70. Armstrong GT, Stovall M, Robison LL. Long-term effects of radiation exposure among adult survivors of childhood cancer: results from the childhood cancer survivor study. Radiat Res (2010) 174:840-50. doi:10.1667/RR1903.1

71. Chow EJ, Friedman DL, Stovall M, Yasui Y, Whitton JA, Robison LL, et al. Risk of thyroid dysfunction and subsequent thyroid cancer among survivors of acute lymphoblastic leukemia: a report from the childhood cancer survivor Study. Pediatr Blood Cancer (2009) 53:432-7. doi:10.1002/pbc.22082 
72. Illouz F, Braun D, Briet C, Schweizer U, Rodien P. Endocrine side-effects of anti-cancer drugs: thyroid effects of tyrosine kinase inhibitors. Eur J Endocrinol (2014) 171:R91-9. doi:10.1530/EJE-14-0198

73. Desai J, Yassa L, Marqusee E, George S, Frates MC, Chen MH, et al. Hypothyroidism after sunitinib treatment for patients with gastrointestinal stromal tumors. Ann Intern Med (2006) 145:660-4. doi:10.7326/0003-4819-145-9200611070-00008

74. Illouz F, Laboureau-Soares S, Dubois S, Rohmer V, Rodien P. Tyrosine kinase inhibitors and modifications of thyroid function tests: a review. Eur JEndocrinol (2009) 160:331-6. doi:10.1530/EJE-08-0648

75. Ishiguro H, Yasuda Y, Tomita Y, Shinagawa T, Shimizu T, Morimoto T, et al. Long-term follow-up of thyroid function in patients who received bone marrow transplantation during childhood and adolescence. J Clin Endocrinol Metab (2004) 89:5981-6. doi:10.1210/jc.2004-0836

76. Sanders JE, Hoffmeister PA, Woolfrey AE, Carpenter PA, Storer BE, Storb RF, et al. Thyroid function following hematopoietic cell transplantation in children: 30 years' experience. Blood (2009) 113:306-8. doi:10.1182/blood-200808- 173005

77. Jung YJ, Jeon YJ, Cho WK, Lee JW, Chung NG, Jung MH, et al. Risk factors for short term thyroid dysfunction after hematopoietic stem cell transplantation in children. Kor J Pediatr (2013) 56:298-303. doi:10.3345/kjp.2013.56.7.298

78. Sklar C, Boulad F, Small T, Kernan N. Endocrine complications of pediatric stem cell transplantation. Front Biosci (2001) 6:G17-22.

79. Au WY, Lie AK, Kung AW, Liang R, Hawkins BR, Kwong YL. Autoimmune thyroid dysfunction after hematopoietic stem cell transplantation. Bone Marrow Transplant (2005) 35:383-8. doi:10.1038/sj.bmt.1704766

80. Savani BN, Koklanaris EK, Le Q, Shenoy A, Goodman S, Barrett AJ. Prolonged chronic graft-versus-host disease is a risk factor for thyroid failure in long-term survivors after matched sibling donor stem cell transplantation for hematologic malignancies. Biol Blood Marrow Transplant (2009) 15:377-81. doi:10.1016/j.bbmt.2008.11.032

81. Rini BI, Tamaskar I, Shaheen P, Salas R, Garcia J, Wood L, et al. Hypothyroidism in patients with metastatic renal cell carcinoma treated with sunitinib. J Nat Cancer Inst (2007) 99:81-3. doi:10.1093/jnci/djk008

82. Torino F, Barnabei A, Paragliola R, Baldelli R, Appetecchia M, Corsello SM Thyroid dysfunction as an unintended side effect of anticancer drugs. Thyroid (2013) 23:1345-66. doi:10.1089/thy.2013.0241

83. Veiga LH, Bhatti P, Ronckers CM, Sigurdson AJ, Stovall M, Smith SA, et al. Chemotherapy and thyroid cancer risk: a report from the childhood cancer survivor study. Cancer Epidemiol Biomarkers Prev (2012) 21:92-101. doi:10.1158/1055-9965.EPI-11-0576

84. Reulen RC, Frobisher C, Winter DL, Kelly J, Lancashire ER, Stiller CA, et al. Long-term risks of subsequent primary neoplasms among survivors of childhood cancer. JAMA (2011) 305:2311-9. doi:10.1001/jama.2011.747

85. Taylor AJ, Croft AP, Palace AM, Winter DL, Reulen RC, Stiller CA, et al. Risk of thyroid cancer in survivors of childhood cancer: results from the British childhood cancer survivor Study. Int J Cancer (2009) 125:2400-5. doi:10.1002/ijc.24581

86. Bhatti P, Veiga LH, Ronckers CM, Sigurdson AJ, Stovall M, Smith SA, et al. Risk of second primary thyroid cancer after radiotherapy for a childhood cancer in a large cohort study: an update from the childhood cancer survivor study. Radiat Res (2010) 174:741-52. doi:10.1667/RR2240.1

87. Metzger ML, Howard SC, Hudson MM, Gow KW, Li CS, Krasin MJ, et al. Natural history of thyroid nodules in survivors of pediatric Hodgkin lymphoma. Pediatr Blood Cancer (2006) 46:314-9. doi:10.1002/pbc.20541

88. Sklar C, Whitton J, Mertens A, Stovall M, Green D, Marina N, et al. Abnormalities of the thyroid in survivors of Hodgkin's disease: data from the childhood cancer survivor study. J Clin Endocrinol Metab (2000) 85:3227-32. doi:10.1210/jc.85.9.3227

89. Landier W, Bhatia S, Eshelman DA, Forte KJ, Sweeney T, Hester AL, et al. Development of risk-based guidelines for pediatric cancer survivors: the children's oncology group long-term follow-up guidelines from the children's oncology group late effects committee and nursing discipline. J Clin Oncol (2004) 22:4979-90. doi:10.1200/JCO.2004.11.032

90. Brignardello E, Corrias A, Isolato G, Palestini N, Cordero di Montezemolo L, Fagioli F, et al. Ultrasound screening for thyroid carcinoma in childhood cancer survivors: a case series. J Clin Endocrinol Metab (2008) 93:4840-3. doi:10.1210/jc.2008-1528
91. Kovalchik SA, Ronckers CM, Veiga LH, Sigurdson AJ, Inskip PD, de Vathaire F, et al. Absolute risk prediction of second primary thyroid cancer among 5-year survivors of childhood cancer. J Clin Oncol (2013) 31:119-27. doi:10.1200/ JCO.2012.41.8996

92. Molgaard-Hansen L, Skou AS, Juul A, Glosli H, Jahnukainen K, Jarfelt M, et al. Pubertal development and fertility in survivors of childhood acute myeloid leukemia treated with chemotherapy only: a NOPHO-AML study. Pediatr Blood Cancer (2013) 60:1988-95. doi:10.1002/pbc.24715

93. Ridola V, Fawaz O, Aubier F, Bergeron C, de Vathaire F, Pichon F, et al. Testicular function of survivors of childhood cancer: a comparative study between ifosfamide- and cyclophosphamide-based regimens. Eur J Cancer (2009) 45:814-8. doi:10.1016/j.ejca.2009.01.002

94. Kenney LB, Laufer MR, Grant FD, Grier H, Diller L. High risk of infertility and long term gonadal damage in males treated with high dose cyclophosphamide for sarcoma during childhood. Cancer (2001) 91:613-21. doi:10.1002/10970142(20010201)91:3<613::AID-CNCR1042>3.0.CO;2-R

95. Romerius P, Ståhl O, Moëll C, Relander T, Cavallin-Ståhl E, Wiebe T, et al. Hypogonadism risk in men treated for childhood cancer. J Clin Endocrinol Metab (2009) 94:4180-6. doi:10.1210/jc.2009-0337

96. Lodish MB, Stratakis CA. Endocrine side effects of broad-acting kinase inhibitors. Endocr Relat Cancer (2010) 17:R233-44. doi:10.1677/ERC-10-0082

97. Leiper AD, Grant DB, Chessells JM. Gonadal function after testicular radiation for acute lymphoblastic leukaemia. Arch Dis Child (1986) 61:53-6. doi:10.1136/adc.61.1.53

98. Izard MA. Leydig cell function and radiation: a review of the literature. Radiother Oncol (1995) 34:1-8. doi:10.1016/0167-8140(94)01501-S

99. Kenney LB, Cohen LE, Shnorhavorian M, Metzger ML, Lockart B, Hijiya N, et al. Male reproductive health after childhood, adolescent, and young adult cancers: a report from the Children's Oncology Group. J Clin Oncol (2012) 30:3408-16. doi:10.1200/JCO.2011.38.6938

100. Bramswig JH, Heimes U, Heiermann E, Schlegel W, Nieschlag E, Schellong G. The effects of different cumulative doses of chemotherapy on testicular function. Results in 75 patients treated for Hodgkin's disease during childhood or adolescence. Cancer (1990) 65:1298-302. doi:10.1002/1097-0142(19900315) 65:6<1298::AID-CNCR2820650607>3.0.CO;2-W

101. Afify Z, Shaw PJ, Clavano-Harding A, Cowell CT. Growth and endocrine function in children with acute myeloid leukaemia after bone marrow transplantation using busulfan/cyclophosphamide. Bone Marrow Transplant (2000) 25:1087-92. doi:10.1038/sj.bmt.1702384

102. Meistrich ML. Effects of chemotherapy and radiotherapy on spermatogenesis in humans. Fertil Steril (2013) 100:1180-6. doi:10.1016/j.fertnstert.2013.08. 010

103. Green DM, Zhu L, Zhang N, Sklar CA, Ke RW, Kutteh WH, et al. Lack of specificity of plasma concentrations of inhibin B and follicle-stimulating hormone for identification of azoospermic survivors of childhood cancer: a report from the St Jude lifetime cohort study. J Clin Oncol (2013) 31:1324-8. doi:10.1200/JCO.2012.43.7038

104. Dubey P, Wilson G, Mathur KK, Hagemeister FB, Fuller LM, Ha CS, et al. Recovery of sperm production following radiation therapy for Hodgkin's disease after induction chemotherapy with mitoxantrone, vincristine, vinblastine, and prednisone (NOVP). Int J Radiat Oncol Biol Phys (2000) 46:609-17. doi:10.1016/S0360-3016(99)00338-7

105. Practice Committee of American Society for Reproductive M. Fertility preservation in patients undergoing gonadotoxic therapy or gonadectomy: a committee opinion. Fertil Steril (2013) 100:1214-23. doi:10.1016/j.fertnstert.2013. 08.012

106. Goossens E, Van Saen D, Tournaye H. Spermatogonial stem cell preservation and transplantation: from research to clinic. Hum Reprod (2013) 28:897-907. doi:10.1093/humrep/det039

107. Chemaitilly W, Mertens AC, Mitby P, Whitton J, Stovall M, Yasui Y, et al. Acute ovarian failure in the childhood cancer survivor study. J Clin Endocrinol Metab (2006) 91:1723-8. doi:10.1210/jc.2006-0020

108. Sklar CA, Mertens AC, Mitby P, Whitton J, Stovall M, Kasper C, et al. Premature menopause in survivors of childhood cancer: a report from the childhood cancer survivor study. J Natl Cancer Inst (2006) 98:890-6. doi:10.1093/jnci/djj243

109. Michel G, Socié G, Gebhard F, Bernaudin F, Thuret I, Vannier JP, et al. Late effects of allogeneic bone marrow transplantation for children with acute myeloblastic leukemia in first complete remission: the impact of conditioning 
regimen without total-body irradiation - a report from the Societe Francaise de Greffe de Moelle. J Clin Oncol (1997) 15:2238-46.

110. Rivkees SA, Crawford JD. The relationship of gonadal activity and chemotherapy-induced gonadal damage. JAMA (1988) 259:2123-5. doi:10. 1001/jama.1988.03720140043031

111. Sklar C. Reproductive physiology and treatment-related loss of sex hormone production. Med Pediatr Oncol (1999) 33:2-8. doi:10.1002/(SICI) 1096911X(199907)33:1<2::AID-MPO2>3.3.CO;2-Z

112. Brydoy M, Fossa SD, Dahl O, Bjoro T. Gonadal dysfunction and fertility problems in cancer survivors. Acta Oncol (2007) 46:480-9. doi:10.1080/ 02841860601166958

113. El-Shalakany AH, Ali MS, Abdelmaksoud AA, Abd El-Ghany S, Hasan EA. Ovarian function in female survivors of childhood malignancies. Pediatr Hematol Oncol (2013) 30:328-35. doi:10.3109/08880018.2013.778927

114. Matsumoto M, Shinohara O, Ishiguro H, Shimizu T, Hattori K, Ichikawa M, et al. Ovarian function after bone marrow transplantation performed before menarche. Arch Dis Child (1999) 80:452-4. doi:10.1136/adc.80.5.452

115. Sanders JE, Buckner CD, Amos D, Levy W, Appelbaum FR, Doney K, et al. Ovarian function following marrow transplantation for aplastic anemia or leukemia. J Clin Oncol (1988) 6:813-8.

116. Visser JA, de Jong FH, Laven JS, Themmen AP. Anti-Mullerian hormone: a new marker for ovarian function. Reproduction (2006) 131:1-9. doi:10.1530/rep.1. 00529

117. Lie Fong S, Laven JS, Hakvoort-Cammel FG, Schipper I, Visser JA, Themmen AP, et al. Assessment of ovarian reserve in adult childhood cancer survivors using anti-Mullerian hormone. Hum Reprod (2009) 24:982-90. doi:10.1093/humrep/den487

118. Dewailly D, Andersen CY, Balen A, Broekmans F, Dilaver N, Fanchin R, et al. The physiology and clinical utility of anti-Mullerian hormone in women. Hum Reprod Update (2014) 20:370-85. doi:10.1093/humupd/dmt062

119. Nielsen SN, Andersen AN, Schmidt KT, Rechnitzer C, Schmiegelow K, Bentzen JG, et al. A 10-year follow up of reproductive function in women treated for childhood cancer. Reprod Biomed Online (2013) 27:192-200. doi:10.1016/j. rbmo.2013.04.003

120. Green DM, Whitton JA, Stovall M, Mertens AC, Donaldson SS, Ruymann FB, et al. Pregnancy outcome of female survivors of childhood cancer: a report from the childhood cancer survivor study. Am J Obstet Gynecol (2002) 187:1070-80. doi:10.1067/mob.2002.126643

121. Reulen RC, Zeegers MP, Wallace WH, Frobisher C, Taylor AJ, Lancashire ER, et al. Pregnancy outcomes among adult survivors of childhood cancer in the British childhood cancer survivor study. Cancer Epidemiol Biomarkers Prev (2009) 18:2239-47. doi:10.1158/1055-9965.EPI-09-0287

122. Aisenberg J, Hsieh K, Kalaitzoglou G, Whittam E, Heller G, Schneider R, et al. Bone mineral density in young adult survivors of childhood cancer. J Pediatr Hematol Oncol (1998) 20:241-5. doi:10.1097/00043426-199805000-00010

123. Ostberg JE, Storry C, Donald AE, Attar MJ, Halcox JP, Conway GS. A doseresponse study of hormone replacement in young hypogonadal women: effects on intima media thickness and metabolism. Clin Endocrinol (2007) 66:557-64.

124. Practice Committees of American Society for Reproductive Medicine, Society for Assisted Reproductive Technology. Mature oocyte cryopreservation: a guideline. Fertil Steril (2013) 99:37-43. doi:10.1016/j.fertnstert.2012.09.028

125. Sala A, Barr RD. Osteopenia and cancer in children and adolescents: the fragility of success. Cancer (2007) 109:1420-31. doi:10.1002/cncr.22546

126. Gurney JG, Kaste SC, Liu W, Srivastava DK, Chemaitilly W, Ness KK, et al. Bone mineral density among long-term survivors of childhood acute lymphoblastic leukemia: results from the St. Jude Lifetime Cohort Study. Pediatr Blood Cancer (2014) 61:1270-6. doi:10.1002/pbc.25010

127. te Winkel ML, Pieters R, Hop WC, Roos JC, Bökkerink JP, Leeuw JA, et al. Bone mineral density at diagnosis determines fracture rate in children with acute lymphoblastic leukemia treated according to the DCOG-ALL9 protocol. Bone (2014) 59:223-8. doi:10.1016/j.bone.2013.11.017

128. Pirker-Fruhauf UM, Friesenbichler J, Urban EC, Obermayer-Pietsch B, Leithner A. Osteoporosis in children and young adults: a late effect after chemotherapy for bone sarcoma. Clin Orthop Relat Res (2012) 470:2874-85. doi:10.1007/s11999-012-2448-7

129. Mostoufi-Moab S, Brodsky J, Isaacoff EJ, Tsampalieros A, Ginsberg JP, Zemel $\mathrm{B}$, et al. Longitudinal assessment of bone density and structure in childhood survivors of acute lymphoblastic leukemia without cranial radiation. J Clin Endocrinol Metab (2012) 97:3584-92. doi:10.1210/jc.2012-2393

130. Ogden CL, Carroll MD, Kit BK, Flegal KM. Prevalence of childhood and adult obesity in the United States, 2011-2012. JAMA (2014) 311:806-14. doi:10.1001/jama.2014.732

131. Park MH, Falconer C, Viner RM, Kinra S. The impact of childhood obesity on morbidity and mortality in adulthood: a systematic review. Obes Rev (2012) 13:985-1000. doi:10.1111/j.1467-789X.2012.01015.x

132. Warner EL, Fluchel M, Wright J, Sweeney C, Boucher KM, Fraser A, et al. A population-based study of childhood cancer survivors' body mass index. J Cancer Epidemiol (2014) 2014:531958. doi:10.1155/2014/531958

133. Sklar CA, Mertens AC, Walter A, Mitchell D, Nesbit ME, O'Leary M, et al. Changes in body mass index and prevalence of overweight in survivors of childhood acute lymphoblastic leukemia: role of cranial irradiation. Med Pediatr Oncol (2000) 35:91-5. doi:10.1002/1096-911X(200008)35:2<91::AID$\mathrm{MPO} 1>3.0 . \mathrm{CO} ; 2-\mathrm{G}$

134. Oeffinger KC, Mertens AC, Sklar CA, Yasui Y, Fears T, Stovall M, et al. Obesity in adult survivors of childhood acute lymphoblastic leukemia: a report from the childhood cancer survivor study. J Clin Oncol (2003) 21:1359-65. doi:10.1200/JCO.2003.06.131

135. Garmey EG, Liu Q, Sklar CA, Meacham LR, Mertens AC, Stovall MA, et al. Longitudinal changes in obesity and body mass index among adult survivors of childhood acute lymphoblastic leukemia: a report from the childhood cancer survivor study. J Clin Oncol (2008) 26:4639-45. doi:10.1200/JCO.2008.16.3527

136. Lustig RH, Post SR, Srivannaboon K, Rose SR, Danish RK, Burghen GA, et al. Risk factors for the development of obesity in children surviving brain tumors. J Clin Endocrinol Metab (2003) 88:611-6. doi:10.1210/jc.2002-021180

137. Lustig RH, Hinds PS, Ringwald-Smith K, Christensen RK, Kaste SC, Schreiber RE, et al. Octreotide therapy of pediatric hypothalamic obesity: a doubleblind, placebo-controlled trial. J Clin Endocrinol Metab (2003) 88:2586-92. doi:10.1210/jc.2002-030003

138. Mason PW, Krawiecki N, Meacham LR. The use of dextroamphetamine to treat obesity and hyperphagia in children treated for craniopharyngioma. Arch Pediatr Adolesc Med (2002) 156:887-92. doi:10.1001/archpedi.156.9.887

139. Meacham LR, Sklar CA, Li S, Liu Q, Gimpel N, Yasui Y, et al. Diabetes mellitus in long-term survivors of childhood cancer. Increased risk associated with radiation therapy: a report from the childhood cancer survivor study. Arch Int Med (2009) 169:1381-8. doi:10.1001/archinternmed.2009.209

140. de Vathaire F, El-Fayech C, Ben Ayed FF, Haddy N, Guibout C, Winter D, et al. Radiation dose to the pancreas and risk of diabetes mellitus in childhood cancer survivors: a retrospective cohort study. Lancet Oncol (2012) 13:1002-10. doi:10.1016/S1470-2045(12)70323-6

Conflict of Interest Statement: Dr. Wassim Chemaitilly has accepted speaker fees from Novo Nordisk and JCR Pharmaceuticals (Japan). Dr. Nicole Barnes has no conflicts of interest to disclose.

Received: 04 July 2014; accepted: 06 September 2014; published online: 23 September 2014.

Citation: Barnes $N$ and Chemaitilly W (2014) Endocrinopathies in survivors of childhood neoplasia. Front. Pediatr. 2:101. doi: 10.3389/fped.2014.00101

This article was submitted to Pediatric Endocrinology, a section of the journal Frontiers in Pediatrics.

Copyright (๑) 2014 Barnes and Chemaitilly. This is an open-access article distributed under the terms of the Creative Commons Attribution License (CC BY). The use, distribution or reproduction in other forums is permitted, provided the original author $(s)$ or licensor are credited and that the original publication in this journal is cited, in accordance with accepted academic practice. No use, distribution or reproduction is permitted which does not comply with these terms. 